\title{
The Relationship between Knowledge and Attitude towards Technology Gadget Usage with Students' Socio- Emotions Development
}

\author{
https://doi.org/10.3991/ijim.v12i7.9711 \\ Zakiah Mohamad Ashari $(\varpi)$, Alifa Aliya Ngadiman, \\ Nurul Farhana Zainudin, Nurul Farhana Jumaat \\ Universiti Teknologi Malaysia, Johor Bahru, Malaysia \\ zakiahma@utm.my
}

\begin{abstract}
Gadgets nowdays become one of the most important necessities in human life. The use of gadgets is not only becomes a widespread among adults, but the younger generation also being exposed to this diverse technology gadgets. The gadgets usage among younger generation contributes to the numerous impacts on their socio-emotional development whether in negative or positive ways. Therefore, this study aims to investigate the relationship between knowledge and attitude, towards technology gadget usage and the students' socioemotions development at Tiram, Johor. This study was conducted using quantitative research design and the questionnaires were distributed to 260 students in three schools around the Tiram zone for data collection purpose. Data were analysed using descriptive statistics and Pearson correlation inference statistics to identify the relationship between the two variables. The results of the analysis showed that there was a significant relationship between knowledge and attitudes, towards the gadget usage among students and their socio-emotion's development. The findings of this study indicate that the students' knowledge and attitude towards the gadgets have a relationship with the students' socioemotions. Therefore, this study is important in providing information especially to the schools, parents and students in order to figure out the appropriate alternative on using the gadgets more effectively.
\end{abstract}

Keywords — attitudes, knowledge, socio-emotion, technology gadget

\section{Introduction}

Technology is now one of the most important requirements in human life. The majority of the people use the gadget technology as a tool for communicating, learning and the medium to find information in sync with the purpose of technology developed. The result of technological advancement is not merely the benefits of the industrial sector but it also helps in the field of state education. However, if the convenience of this technology is misused, it can negatively affect individuals or users.

Basically, the use of technology gadgets actually gives various benefits to students especially in relation to learning. Many past studies that illustrate the positive effects 
of technology gadgets in addition to help the student's self-development process. The use of technology gadgets is an effective medium for education, as it provides opportunities for self-learning and educating children to be more creative and innovative [23]. Additionally, learning through technology gadgets may also increase student self-motivation to learn as well as benefits to their intellectual developmental. As stated in [18] also point out that learning through this technology gadget provides opportunities for learners with learning disabilities to learn and have been considered as learning tools for them [4]. This is because technology gadgets contain various types of software and education-related applications and is one of the attractions for children to love learning through an interesting methods.

Other than that, technology gadgets are one of the most effective ways to help students develop the process of fine motor skills. According to researcher in [9], video games can benefit the development of skills as well as smooth motor coordination through kinesthetic responses and visual focus on the game. In addition, video games can also enhance students' thinking skills as well as problem solving skills [35] through the activities provided.

However, the use of gadgets can also be harmful to students when used freely and uncontrollably. Children are at risk of developing physical and health problems due to incorrect body structure when using a technology gadget [4]. This is likely due to the excessive use of gadgets causing the child to be in a static position and the lack of body movements over a long period of time. Exposure to over-screen light also affects children's concentration. Thus, it cause of obesity, sleep disorders, poor learning performance and inhibits social relations between peers (Campaign for a Commercial-Free Childhood \& Alliance for Childhood, 2012) in [35]. The study found that most young people face health problems in the neck and back of the body within a year, as a result of using technology gadgets such as smartphones, computers and video games [23].

Moreover, the students are also faced problems in terms of behavior and relationships with their surrounding due to the exposure of gadgets in early childhood. As mentioned in [36] children loves mimic the behaviors or violence they learn through observations of others. The reasons are because of their level of thinking are limited and they still cannot assess whether the behavior is either wrong or correct. Exposure to risky and harmful behavior leads to the same behavior [35][22]. Exposure and use of technology gadgets to students may affect and influence the student's daily life. Arguments and opinions on the role or function of technology gadgets on child development are still debated [4] until now. However, Dr. Mohammad Iqbal Mohammad Sarwar (Pediatric and Neonatologist Consultant) in the message argued that the use of gadgets or technologies such as smartphones, computers and so on had more negative effects than positive ones for children if used without monitoring from parents [37].

In Malaysia, the use of technology gadgets becomes a widespread not only among adults but also to the younger people. According to researcher in [23], the exposure and use of technology gadgets on children as early as two years old and below is a common practice among Malaysian society. The reasons are some people assume that giving early exposure to technology can help the development of children from the aspects of cognitive, learning, physical, behavioral and social skills. There are also parents and educators who have an opinion by thinking that the children and students need to have 
the skills and expertise in using technology in order to help them build a career when growing up [4]. As stated in [29], children nowadays use technology gadgets as loyal as friends and playmates especially when connected to internet networks; children will be more attracted with the variety of fun and entertainments provided in the gadgets which can interfere with their development. The use of technology gadgets basically brings many effects to the students from a positive angle or vice versa especially regarding to their socio-emotions development, depending on the technique and purpose it uses.

Social and emotional development on a children stage is important, to help them build self-confidence when they grow up; and these development can be fostered through interaction with their environment such as parents, siblings, friends and etc. Students also will be more confident in social relationships and interaction if they have a stable emotion and it's will also shows the potential of students [6]. However, if at the young age the children have been exposed to the use of a gadget and lack of interaction with others, it is indirectly interferes with the development of socio-emotional of the students. The exposure to the gadgets that contain various stimuli such as light, sound and movement cause disruption to children's emotional stability [12] to the extend the children tend to be obsessed with gadgets, show rampage and aggressive action that can cause injury if their desire to play is not met.

In addition, the frequent use of gadget is also related to the level of students' knowledge about technology gadgets. Parents who are too trivial and trust their children in using technology gadgets [32] are one of the factors contributing to the improvement in the level of knowledge and the efficiency of the students in handling the gadgets. Majority of parents have a positive perception of the gadget usage among their children. They argue that the use of a gadget on younger age can help children build a career [4], giving children the opportunity to sharpen their social skills in a new environment [8] and to encourage response through video games [9]. On the other hand, the parents are not aware that the early exposure of the gadget to children is a contributor to the increase in knowledge and skills of the children about the gadget. These young people will be more motivated to spend more time playing with gadgets because of their level of mastery and greater knowledge in managing the tools than adults. Children who spend more time on technology gadgets are also reported to have lower levels of selfesteem and tend to get more frequent problems [13]. Student emotions are also disturbed because they are easy to feel tired and sad compared to their other colleagues [5] when they are not given a gadget.

Student attitudes towards gadgets are also alarming and affect the socio-emotional development of students. Undoubtedly, the children only show a positive attitude when a given gadgets is just for play and usually parents will use this way as a bait to control their children's behavior in public or at home [32]. But, there are also parents who use gadgets as one of the learning methods to help and encourage children with disabilities to study [18]. However, when children are often given gadgets to play, it has negative impacts on them. According to researcher in [27], children prefer to play with technology tools because they have a variety of attractions in terms of functionality and interactive features that bring an addiction to themselves. Addiction and obsessiveness of this technology is also due to the exposure provided regardless of age and no monitoring 
from parents. However, not all students show a positive attitude towards the gadget. Some students prefer using gadgets for personal and entertainment purposes rather than lessons [34] and interest in technology also depends on gender [33] and the level of students' mastery of technology. Previously, most of the studies conducted only focus on the effect of using a gadget on student attitudes when the technology is implemented in learning and teaching sessions; is not reviewed in depth including the use of gadgets in their daily lives.

Moreover, reports from the Malaysian Statistics Department [16] also show an increase rate the use of technology gadgets (such as computer, hand phone and internet) for a person from year 2013 to $2015 ; 14.1$ percent for internet, 12.7 percent for computer, 3.3 percent for hand phone and this includes users in children. Based on the statistics, this issue is particularly concerned by various parties, especially parents and educators as it is a challenge for them to grow up and educate their children or students in the best possible way in line with today's sophisticated technology. Consequently, studies on the use of gadgets and their social-emotional connections are still poorly implemented. Most of the previous studies discussed more about the impact of technology on social aspects [7][20][22][23] but the socio-emotional aspects of the students are still under emphasis. Thus, this study was conducted to identify two relationships which are the relationship between knowledge of the gadget and the socio-emotion of the students and the attitudes towards the gadget and its relation to the socio-emotion of the students.

\section{Methodology}

This study was used a quantitative research design by conducting a survey. The sampling method used was a cluster sampling involving 260 primary school students around Johor Bahru. A set of questionnaires is distributed to each respondent and consists of four parts, namely Part A, Part B, Part C and Part D. Part A consists of items related to respondent's demographic information such as gender, race, average time using a gadget, the type of gadgets used and the purpose of using the gadgets. In the meantime, Section B consists of 16 items relating to student knowledge about the gadgets and this instrument is adapted from the study in [31] while Section C consists of 33 items related to student attitudes towards the gadgets and adapted from the study conducted in [14]. Both instruments in Section B and Section C are modified according to the needs of the study. Part D uses the Bar-On Emotional Quotient-Intelligence (EQ-i: Youth Version) instrument which consists of 30 items to measure the social and emotional levels of the respondents of the study. This instrument uses a 4-point Likert scale with scale 1 (Strongly Disagree) and scale 4 (Strongly Agree). The validity and reliability of the instruments are also been tested using Cronbach Alpha value to ensure that the instruments are valid and research objectives are achieved. The value of Cronbach Alpha for three instruments is range between $\alpha=0.66$ to 0.75 which means acceptable for the researcher to conduct the study. Data collected then were analyzed using descriptive and inferential statistics to achieve the objectives of the study. Descriptive analysis were used to identify the level of knowledge, attitudes and socio-emotional 
levels of students, while inference analysis was used to study the relationship between knowledge variables and attitudes towards technology gadgets with students' socioemotions.

\section{$3 \quad$ Research Findings}

The findings of this study were based on the questions and objectives of the study. Table 1 showed the findings of respondents' demographic information such as gender, race, type of gadgets used frequently, average daily use of gadgets and the purpose of using the gadgets. While, Table 2 indicate that the level of knowledge, attitudes and socio-emotions of the students and from the results it shows that most of the students have high level in the three aspects that been measured by researcher.

Table 1. Demographic Information by Frequency and Percentage

\begin{tabular}{|c|c|c|c|}
\hline Item & & Frequency $(f)$ & Percentage (\%) \\
\hline \multirow{2}{*}{ Gender } & Male & 128 & $49.2 \%$ \\
\hline & Female & 132 & $50.8 \%$ \\
\hline \multirow{4}{*}{ Race } & Malay & 224 & $86.2 \%$ \\
\hline & Chinese & 3 & $1.2 \%$ \\
\hline & Indian & 24 & $9.2 \%$ \\
\hline & Others & 9 & $3.5 \%$ \\
\hline \multirow{5}{*}{ Type of Gadget } & Computer & 31 & $8.7 \%$ \\
\hline & Laptop & 58 & $16.2 \%$ \\
\hline & Handphone & 28 & $7.8 \%$ \\
\hline & Smartphone & 205 & $57.4 \%$ \\
\hline & Tablet & 35 & $9.8 \%$ \\
\hline \multirow{5}{*}{ Time Average } & Less than 1 hour & 60 & $23.1 \%$ \\
\hline & Between 1 to 2 hours & 74 & $28.5 \%$ \\
\hline & Between 2 to 3 hours & 66 & $25.4 \%$ \\
\hline & Between 3 to 4 hours & 21 & $8.1 \%$ \\
\hline & More than 4 hours & 39 & $15.0 \%$ \\
\hline \multirow{5}{*}{ Gadget Usage Purpose } & Calling and Sending SMS & 98 & $19.5 \%$ \\
\hline & Browsing media social & 134 & $26.7 \%$ \\
\hline & Learning purpose & 87 & $17.3 \%$ \\
\hline & Playing video games & 102 & $20.3 \%$ \\
\hline & Watching videos and films & 81 & $16.1 \%$ \\
\hline
\end{tabular}

The respondents of this study consisted of 128 male students (49.2\%) and 132 female students $(50.8 \%)$ out of 260 students. The majority of the respondents were 224 Malay students $(86.2 \%)$, followed by $24(9.2 \%)$ Indian students, the others race such as Iban and Kadazan is 9 students (3.5\%) and the least number of students is Chinese which is only 3 students (1.2\%). The findings also found that three types of gadgets mostly used by students were smartphones (57.4\%), laptops $(16.2 \%)$ and tablets $(9.8 \%)$. 
Furthermore, researchers found that students' time spent between 1 hour and 2 hours (28.5\%), between 2 hours to 3 hours $(25.4 \%)$ and less than 1 hour $(23.1 \%)$ to use the gadgets within a day. However, there were also students who used gadgets ranging from 3 hours to 4 hours $(8.1 \%)$ and even more than 4 hours $(15.0 \%)$ per day on average. In addition, the main purpose of students to use the gadget is to browse social media $(26.7 \%)$ and play video games $(20.3 \%)$, in addition to basic functions such as calling and sending short messages (SMS) (19.5\%). There were also some students who use gadgets for learning purposes $(17.3 \%)$ and watch videos or movies $(16.1 \%)$ through a gadget application.

Table 2. The Level of Knowledge, Attitude and Students' Socio-Emotion

\begin{tabular}{|l|c|c|c|}
\hline \multicolumn{1}{|c|}{ Item } & Mean & Standard Deviation & Level \\
\hline Level of Students' Knowledge towards Gadget & 3.26 & 0.39 & High \\
\hline Level of Students' Attitude towards Gadget & 3.03 & 0.30 & High \\
\hline Level of Students' Socio-Emotion & 3.02 & 0.33 & High \\
\hline
\end{tabular}

Based on Table 2, descriptive analysis was conducted to identify students' level of knowledge, attitudes and socio-emotions on the gadget and it was explained based on the mean value and standard deviation. The findings showed that the level of knowledge, attitude and socio-emotion of students related to the gadgets were at a high level which were $\mathrm{M}=3.26$, $\mathrm{SP}=0.39$ for the student's knowledge level, while $\mathrm{M}=$ $3.03, \mathrm{SP}=0.30$ for student attitudes towards the gadgets and $\mathrm{M}=3.02, \mathrm{SP}=0.33$ for the socio-emotional level of students in the Tiram Zone.

Table 3. The Relationship between Gadget Knowledge and Students' Socio-Emotion

\begin{tabular}{|c|l|c|c|}
\hline & & Gadget Knowledge & Socio-Emotion \\
\hline \multirow{3}{*}{ Gadget Knowledge } & Pearson Correlation & 1.00 & $0.27^{* *}$ \\
& Sig. (2-tailed) & 260 & 0.00 \\
& $\mathrm{~N}$ & & 260 \\
\hline
\end{tabular}

${ }^{* * *}$ Correlation is significant at level 0.01

Table 4. The Relationship between Attitude towards Gadget and Students' Socio-Emotion

\begin{tabular}{|l|l|c|c|}
\hline & & Attitude towards Gadget & Socio-Emotion \\
\hline \multirow{3}{*}{ Attitude towards Gadget } & Pearson Correlation & 1.00 & $0.34^{* *}$ \\
& Sig. (2-tailed) & 260 & 0.00 \\
& $\mathrm{~N}$ & & 260 \\
\hline
\end{tabular}

${ }^{* *}$ Correlation is significant at level 0.01

In addition, inferential analysis was also conducted to examine the relationship between the study variables. Table 3 shows that there is a positive correlation between the knowledge of the gadget and the student socio-emotion which were $r=0.27, n=260$, $p=0.00$. Meanwhile, the relationship between attitudes toward the gadget and the student's socio-emotion also shows the same finding where there is a positive correlation between the variables with $\mathrm{r}=0.34, \mathrm{n}=260, \mathrm{p}=0.00$ (Refer Table 4). Through these values, it can be concluded that there is a significant but weak relationship between 
knowledge of technology gadget with students' socio-emotions and attitudes toward the gadget with the socio-emotional of students. Hence, both hypotheses of the study $\left(\mathrm{H}_{0} 1\right.$ and $\left.\mathrm{H}_{0} 2\right)$, there is no significant relationship between the level of knowledge and attitude towards the gadget with the socio-emotion of the student being rejected.

\section{Discussion}

The main objective of this study is to identify two relationships between the three variables namely knowledge and attitude towards technology gadgets with student socio-emotions. Therefore, in order to achieve the main objectives of the study, the researcher also measures the level of student's knowledge about the gadgets, the level of student attitudes towards the gadgets and the socio-emotional level of the students. Overall, the level of knowledge, attitudes and socio-emotions of students was high; with 194 students (74.6\%) having a high level of knowledge about the gadgets, while 134 students $(51.4 \%)$ had a high level of attitudes towards the gadgets and 137 students $(52.7 \%)$ had a high socio-emotional level of 260 students.

As stated in [3], knowledge of technology gadgets includes the basic knowledge of technology gadgets and high-tech knowledge. High technology knowledge includes the individual ability to handle various technology gadgets, install and remove any applications or software related to the gadgets [19]. The results of this study show that the average student has a high degree of control over handling a technology gadget. Students learn not only to handle the basic functions of a gadget such as calling and sending short messages (SMS), but students are also competent in handling gadgets with various applications and more critical functions such as editing a photo, browsing a social site, watching videos and so on. This is also supported by the study in United State [32] which shows that the level of child knowledge about technology gadgets is higher than the perception of their own parents. Knowledge of this technology gadget is dominated by students through sharing and exposure from student environments such as peers, adults and family members. In other research, author found that eventhough the children are still young but they also smart in handling gadgets like the iPad because they already have their own experience in using technology gadgets while at home [15]. From this study, it proves that early exposure of tech gadgets to children can further heighten their knowledge of the use of gadgets as compared to adults. However, research findings on the aspect of student's knowledge about gadgets are very limited, as studies are still poorly implemented both inside and outside the country.

On other hand, the findings about student's attitude toward gadgets technology are also impressive with the total of 134 out of 260 students' shows positive attitude towards the use of gadgets in their life. This result is in line with the study conducted in [34] found most of students demonstrate positive behavior towards the use of gadgets regardless of teaching and learning sessions or everyday life (for personal purpose). It is also proven based on the Table 1 showing that the main purpose student's use gadget is to surf social media $(26.7 \%)$ and play video games $(20.3 \%)$ compared to learning (17.3\%). Therefore, one of the alternatives to attract students' enthusiasm to learn in schools is through technology gadgets. As mentioned in [18], the use of gadgets is also 
one of the motivational tools for students especially those who have learning problems. Based on the findings in [15] which embraced the use of gadgets such as the iPad in learning showed a positive attitude among students although at first there were students who had difficulty in handling the gadgets but they still had an interest and effort to learn to operate the iPad gadgets. However, the findings from the study in [11] show a different result because even though the students have positive perception and knowledge about gadgets, but did not have a positive attitude towards the gadgets in learning. This is likely due to the main factor affecting the student to use the gadgets; as mentioned earlier students are more preferred to use gadget as personal purpose rather than for learning. Other factors such as gender differences may also influence student attitudes towards technology gadgets and it's been found in the previous study [21]. The findings show although most of the students have positive attitudes towards gadgets but male students are more positive and more confident in using technology gadgets than girls.

The level of student's socio-emotions also been measured in order to achieve the main objectives of this study. Findings found that the level of student's socio-emotions is high with a total of 137 students' and this shows that most students have a healthy level of intelligence and better socio-emotional development. This finding is also supported by researcher in [28] which sets out environmental factors such as parents affect the high level of emotions intelligence among students. If students are master in social skills, it will helps an individuals in managing a wide range of emotions experienced as well as effective relationships with other people [24]. Socio-emotional development of students may occur due to various aspects which influence such as family background, socioeconomic status, peers or technology. The socio-emotional developmental also often associated with students ' academic achievement. It's proven through the study [26], where's the findings show that students who have a high level of emotional intelligence is capable of achieving high academic performance.

Moreover, the findings of the relationship between knowledge and attitudes towards the gadget with the socio-emotion of the students showed that there was a significant but weak relationship between the knowledge about gadget with student's socio-emotion and also the student's attitudes towards the gadget with their socio-emotion. This finding explains that the level of knowledge and attitudes can influence the development of socio-emotional students who are also at high levels. This has been proven through the research carried out in [17] where the students who often use technology gadgets have a high level of emotional maturity compared to those who lack technology gadgets. The results in [25] also support this findings by stated that technological gadgets also not only emit one's emotions but also serve as one of the channels for users to express love with others and this is parallel to the main function of technology gadgets as one of the means of communication to establish relationships between individuals with someone else. However, the findings of this study are contrary to the findings in [2] that found there is no significant relationship between attitudes towards learning using computer gadgets with students' socio-emotional intelligence. The findings of this study emphasize more on the correlation between student socio-emotional intelligence and effective learning method using technology gadgets [2]. However, as a whole, the use of technology gadgets has had a negative impact on student socio- 
emotions as described in previous studies [7][22][34], but has a positive impact in the aspects of learning and motivation of students. The reason is students emphasize the element of excitement and self-satisfaction which they can get from the gadget. Students 'attitudes towards the gadgets also have links with students' self-motivation. The use of gadget applied in teaching and learning sessions in schools mostly to enhance students' motivation in learning by using more relaxed and effective methods $[1][10][30][34]$ rather than focusing on student's socio-emotion development.

\section{Recommendation}

Based on the discussion of the results of the above study, there are some suggestions to further this study in the future. Firstly, It is recommended that the researcher in the future to expand the level of student's age. The main reasons because of this study were more focused on the primary students in the Tiram Zone area to see the level of knowledge, attitude and socio-emotion of the students. However, if the future researcher can include other level of student's age (such as pre-school, secondary or college students) it will shows a different results because of the middle-aged students have a wider range of knowledge and maturity than lower-level students.

Other than that, this study is conducted only in the Tiram Zone and involves only a few schools within the Tiram Zone area. Hence, it does not reflect the overall level of knowledge, attitude and socio-emotional level of students. Therefore, the location of the study can be further expanded to other city, district or country so that samples are larger and have different respondent backgrounds.

Lastly, the method used in this study is a questionnaire where there are limitations and transparency of respondents' responses to the questionnaire and it's beyond the researcher's control. Therefore, future studies can be developed using other research methods such as interviews or observations to obtain clearer and more accurate findings.

\section{Conclusion}

The purpose of this study was to provide a clear picture and understanding of the relationship between knowledge and attitudes towards technology gadgets with students' socio-emotions. Therefore, the findings from this study found that there was a significant relationship between the three variables of the study and showed that each party should look seriously in relation to the technology gadgets as it can influence and impact on the socio-emotion of students as well as children. Collaboration and role from parents and schools also need to be played to control the use of technology gadgets among students. Parents and schools need to balance students with healthier activities that can promote social interaction relationships to assist in the development of socioemotional students. Hence, the suggestions raised can give some insights and ideas to future researchers for welfare so as to give more benefits and benefits to all parties, especially parents and students. 


\section{$7 \quad$ Acknowledgment}

The authors would like to thank Universiti Teknologi Malaysia (UTM) and the Ministry of Education (MOE) for their encouragement of this project. This project is under Fundamental Research Grant Studies (Vote No: R. J130000. 7831. 4F873).

\section{$8 \quad$ References}

[1] A Rahim, N. (2013). Penggunaan mobile learning (m-learning) untuk tujuan pembelajaran dalam kalangan pelajar kejuruteraan UTHM. Universiti Tun Hussein Onn Malaysia.

[2] Behnken, C., \& Greenan, J. P. (2011). The relationship between emotional intelligence and attitudes toward computer-based instruction of postsecondary hospitality students. Journal of Career and Technical Education, 26(1), 62-84.

[3] Brown, A. (2015). Development of Technology Knowledge and Beliefs: Does Instructional Modality Matter?, Creighton University.

[4] Ebbeck, M., Yim, H. Y. B., Chan, Y., \& Goh, M. (2016). Singaporean parents' views of their young children's access and use of technological devices. Early Childhood Education Journal, 44(2), 127-134. https://doi.org/10.1007/s10643-015-0695-4

[5] Garrison, M. M., Liekweg, K., \& Christakis, D. A. (2011). Media Use and Child Sleep: The Impact of Content, Timing, and Environment. Pediatrics. doi: 10.1542/peds.2010-3304. https://doi.org/10.1542/peds.2010-3304

[6] Hassim, S., CHUA, C. T., Majid, R. A., Jelas, Z. M., \& Yusof, H. A. M. (2012). Perkembangan Kecerdasan Emosi Kanak-kanak Prasekolah Bermasalah Pendengaran: Implikasinya Terhadap Penglibatan Ibu Bapa (The Emotional Intelligence Development of Pre-Schoolers with Hearing Difficulties: Implications on Parental Involvement). Akademika, 82(2), 137142 .

[7] Heim, J., Brandtzaeg, P. B., Kaare, B. H., Endestad, T., \& Torgersen, L. (2007). Children's usage of media technologies and psychosocial factors. New Media \& Society, 9(3), 425454. https://doi.org/10.1177/1461444807076971

[8] Highfield, K. (2010). Possibilities and pitfalls of techno-toys and digital play in mathematics learning.

[9] Howard-Jones, P. (2011). The impact of digital technologies on human wellbeing: Evidence from the sciences of mind and brain: Nominet Trust.

[10] Hsin, C.-T., Li, M.-C., \& Chin-Chung, T. (2014). The influence of young children's use of technology on their learning: A review. Journal of Educational Technology \& Society, $17(4), 85$.

[11] Incantalupo, L., Treagust, D. F., \& Koul, R. (2014). Measuring student attitude and knowledge in technology-rich biology classrooms. Journal of Science Education and Technology, 23(1), 98-107. https://doi.org/10.1007/s10956-013-9453-9

[12] Khan, F. F. F. (2015). Baik, mudarat gajet atas pilihan, Harian Metro. Retrieved from http://www.hmetro.com.my/node/76176? $\mathrm{m}=1$

[13] Kim, Y. (2013). Young Children in the Digital Age.

[14] Knezek, G., \& Christensen, R. (1996). Validating the Computer Attitude Questionnaire (CAQ).

[15] Laili Farhana, M., Norhayati, B., \& Maizatul Hayati, M. (2013). A Field Study of Understanding Child's Knowledge, Skills and Interaction Towards Capacitive Touch Technology 
(iPad). Paper presented at the 2013 8th International Conference on Information Technology in Asia (CITA 2013). IEEE.

[16] Malaysia, L. W. R. J. S. (2016). ICT Use and Access by Individuals and Households Survey Report Malaysia, 2015.

[17] Mamatha, S., Hanakeri, P. A., \& Aminabhavi, V. A. (2016). Impact of gadgets on emotional maturity, reasoning ability of college students. IJAR, 2(3), 749-755.

[18] Mioduser, D., Tur-Kaspa, H., \& Leitner, I. (2000). The learning value of computer-based instruction of early reading skills. Journal of computer assisted learning, 16(1), 54-63. https://doi.org/10.1046/j.1365-2729.2000.00115.x

[19] Mishra, P., \& Koehler, M. J. (2006). Technological pedagogical content knowledge: A framework for teacher knowledge. Teachers college record, 108(6), 1017. https://doi.org/10.1111/j.1467-9620.2006.00684.x

[20] Muduli, J. (2014). Addiction to technology gadgets and its impact on health and lifestyle: a study on college students.

[21] Pierce, R., Stacey, K., \& Barkatsas, A. (2007). A scale for monitoring students' attitudes to learning mathematics with technology. Computers \& Education, 48(2), 285-300. https://doi.org/10.1016/i.compedu.2005.01.006

[22] Ray, M., \& Jat, K. R. (2010). Effect of electronic media on children. Indian pediatrics, 47(7), 561-568. https://doi.org/10.1007/s13312-010-0128-9

[23] Salmah, O., \& Malisah, L. (2015). Pengaruh Peranti Teknologi Kepada Perkembangan Sosial Dan Permasalahan Kesihatan Kanak-Kanak. 1-12.

[24] Schutte, N. S., Malouff, J. M., Bobik, C., Coston, T. D., Greeson, C., Jedlicka, C., . . Wendorf, G. (2001). Emotional intelligence and interpersonal relations. The Journal of social psychology, 141(4), 523-536. https://doi.org/10.1080/00224540109600569

[25] Serrano-Puche, J. (2015). Emotions and digital technologies: Mapping the field of research in media studies.

[26] Sidek, S. (2013). Hubungan kecerdasan emosi dengan pencapaian akademik dalam kalangan pelajar-pelajar kolej Vokasional Kementerian Pelajaran Malaysia (KVKPM). Universiti Tun Hussein Onn Malaysia.

[27] Siu, K. W. M., \& Lam, M. S. (2005). Early childhood technology education: A sociocultural perspective. Early Childhood Education Journal, 32(6), 353-358. https://doi.org/10.1007/ s10643-005-0003-9

[28] Sulaiman, H. (2013). Hubungan antara kecerdasan emosi dengan gaya asuhan ibu bapa dalam kalangan remaja sekolah. Fakulti Pendidikan, Universiti Malaya.

[29] Tamayo, J. D., \& dela Cruz, G. S. G. (2014). The Relationship of Social Media with the Academic Performance of Bachelor of Science in Information Technology Students of Centro Escolar University-Malolos. International Journal of Scientific and Research Publications, 4(5), 1-10.

[30] Tveit, Å. K., \& Mangen, A. (2014). A joker in the class: Teenage readers' attitudes and preferences to reading on different devices. Library \& Information Science Research, 36(3), 179-184. https://doi.org/10.1016/j.lisr.2014.08.001

[31] Van Deursen, A. J. A. M., Helsper, E. J., \& Eynon, R. (2014). Measuring digital skills. From digital skills to tangible Outcomes project report.

[32] Vittrup, B., Snider, S., Rose, K. K., \& Rippy, J. (2016). Parental perceptions of the role of media and technology in their young children's lives. Journal of Early Childhood Research, 14(1), 43-54. https://doi.org/10.1177/1476718X14523749

[33] Volk, K., Yip, W. M., \& Lo, a. T. K. (2003). Hong Kong Pupils' Attitudes Toward Technology: The Impact of Design and Technology Programs. Journal of Technology Education, 15(1), 48-63. https://doi.org/10.21061/jte.v15i1.a.4 
[34] White, J., \& Mills, D. J. (2014). Examining attitudes towards and usage of smartphone technology among Japanese university students studying EFL. CALL-EJ, 15(2), 1-15.

[35] Ernest, J. M., Causey, C., Newton, A. B., Sharkins, K., Summerlin, J., \& Albaiz, N. (2014). Extending the global dialogue about media, technology, screen time, and young children. Childhood Education, 90(3), 182-191. https://doi.org/10.1080/00094056.2014.910046

[36] Christakis, D. A. (2009). The effects of infant media usage: what do we know and what should we learn? Acta Paediatrica, 98(1), 8-16. https://doi.org/10.1111/j.16512227.2008.01027.x

[37] Yusoff, S. A. (2014). Gajet ibarat pengasuh kedua, Utusan. Retrieved from http://ww1.utusan.com.my/utusan/Keluarga/20140102/ke_01/Gajet-ibarat-pengasuhkedua.

\section{Authors}

Zakiah Mohamad Ashari has earned her Ph.D. in Educational Psychology from Universiti Teknologi Malaysia in 2014. Currently, she works as a senior lecturer at Faculty of Education in Universiti Teknologi Malaysia.

Alifa Aliya Ngadiman has received master's degree in Educational Psychology from the University of Technology Malaysia in 2018.

Nurul Farhana Zainudin has received master's degree in Educational Psychology from the University of Technology Malaysia in 2016. Currently, she is a Ph.D. student in the Department of Psychology, Universiti Teknologi Malaysia.

Nurul Farhana Jumaat has earned her Ph.D. in Educational Technology from Universiti Teknologi Malaysia in 2014. Currently, she works as a senior lecturer at Department of Educational Sciences, Mathematics and Multimedia Creative, Faculty of Education, Universiti Teknologi Malaysia.

Article submitted 28 September 2018. Resubmitted 14 October 2018. Final acceptance 01 November 2018. Final version published as submitted by the authors. 